\title{
Effect of Nickel in the Irrigation Water and Foliar Applied Malic Acid on Vegetative Growth, Flowering and Chemical Composition of Salvia splendens Plant
}

\author{
Nader A. El-Shanhorey ${ }^{1}$ and Galal A. Saker ${ }^{2}$ \\ ${ }^{1}$ Botanical Gardens Research Department, Horticultural Research Institute, ARC, Alexandria, Egypt. \\ ${ }^{2}$ Botanical Gardens Research Department, Horticulture Research Institute, ARC, Geza, Egypt.
}

\begin{abstract}
The present study was carried-out at Antoniadis Research Branch, Horticultural Research Institute, A.R.C. Alexandria, Egypt during the two successive seasons 2016 and 2017. The aim of this study was to evaluate the effects of irrigation water contaminated with nickel on Salvia splendens plants grown in sandy soil. The possibility of using malic acid spray treatments to overcome the effects of nickel pollution. Seedlings of Salvia splendens were planted individually in plastic pots ( $20 \mathrm{~cm}$ diameter) filled with $3 \mathrm{~kg}$ of sandy soil. Four concentrations of nickel 0,100, 200 and $300 \mathrm{ppm}$ were applied in the irrigation water. The plants were treated with malic acid at concentrations of 0,250 and 500 ppm by monthly spraying in both seasons.

The results showed that for vegetative and flowering growth parameters, there was no significant interaction between nickel concentrations and foliar spray by malic acid, while a significant reduction was observed in all parameters after irrigation with contaminated water contained nickel and a significant increase in vegetative and flowering growth parameters was observed after $500 \mathrm{ppm}$ malic acid application. For chlorophyll and carbohydrate content the highest significant value was obtained from plants irrigated with tap water and sprayed with $500 \mathrm{ppm}$ malic acid while the highest significant nickel content in leaves, stem and roots was obtained in the treatment $300 \mathrm{ppm}$ without application of malic acid.
\end{abstract}

Key wards: Salvia splendens - Nickel - Malic acid.

\section{INTRODUCTION}

The genus Salvia (Fam.: Lamiaceae), consists of approximately 900 species including shrubs, herbaceous perennials and annuals (Karousou et al., 2000). Salvia splendens plants were originated in Brazil. Many studies have focused only on sage's secondary metabolites which has aromatic and medicinal properties (Topcu, 2006). Salvia splendens is considered as one of the most commonly observed ornamental plants in the landscape. $\mathrm{Wu}$ et al. (2001) mentioned that landscape and floricultural plants, are damaged due to low or moderate salinity on the irrigation water.

The concentrations of heavy metals increase in the environment from year to year (Govindasamy, 2011). Plants need trace amount of heavy metal but their availability in the excess may cause plant toxicity (Sharma et al., 2006). Phytotoxic concentration of the heavy metals referred in the literature does not always specify the levels (Wua et al., 2010). Nickel is also released into the environment from anthropogenic activities, such as industrial wastes, fertilizer application and organic manures (Salt, 2000). Nickel is essential for plants (Ragsdale, 1998). It has been identified as a component of a number of enzymes, including glyoxalases, peptide deformylases and a few superoxide dismutases and hydrogenases (Kupper and Kroneck, 2007). Therefore nickel plays a role in various important metabolic processes, including ureolysis, hydrogen metabolism, methanbiogenes and acitogensis (Mulrooney and Hausinger, 2003). Toxic effects of high concentrations of nickel in plants have been frequently reported, for example inhibition of mitotic activities (MadhavaRao and Sresty, 2000), reductions in plant growth (Molas, 2002) and adverse effects on fruit yield and quality (Gajewska et al., 2006). Extremely high soil nickel concentrations have left some farmland unsuitable for growing crops, fruits and vegetables (Duarte et al., 2007).

Malic acid is an organic dicarboxylic acid formed in the metabolic cycles in the cells of plants, and plays a key role in the energy-producing Krebs cycle. Therefore, they can influence the cut flower's vase life (da Silva, 2003). Malic acid is the organic acid which could be metabolized by reaction of malic enzyme in plant mitochondria by reaction of malic enzyme and this is considered as ability limited to plant (Day and Hanson, 1977).

In this study Salvia splendens was selected due to its characteristics as non-edible plant, therefore the objective of this study is to evaluate the effects of irrigation water contaminated with nickel on Salvia plants and to investigate the response of these plants to malic acid spray treatments to decrease the harmful effect of nickel pollution in the irrigation water, determine the potential of Salvia in removing nickel from the soil and contaminated irrigated water and to investigate on the ability of Salvia in removing nickel. 


\section{MATERIALS AND METHODS}

The present study was carried-out at Antoniadis Research Branch, Horticultural Research Institute, A.R.C. Alexandria, Egypt during the two successive seasons 2016 and 2017. The aim of this study was to evaluate the effects of irrigation water contaminated with nickel on Salvia splendens plants grown in sandy soil and the possibility of using malic acid spray treatments to overcome the effects of nickel pollution. The seedlings used to establish the experiment were brought from a commercial nursery in Alexandria as local produced seedlings of Salvia splendens.

On the $3^{\text {th }}$ of January, 2016 and 2017 in the first and second seasons, respectively, homogeneous seedlings of Salvia splendens (14-16 cm height and 9-11 leaves per plant in average) were planted individually in plastic pots $(20 \mathrm{~cm}$ diameter $)$ filled with $3 \mathrm{~kg}$ of sandy soil. The chemical constituents of the soil were determined as described by Jackson (1958) in Table (1).

On the $15^{\text {th }}$ of January in both seasons, the contaminated irrigation water treatments were started. Four concentrations of nickel chloride $\left[\mathrm{NiCl}_{2} \cdot 6 \mathrm{H}_{2} \mathrm{O}\right]$ 0,100, 200 and 300 ppm were applied. The plants were irrigated three times per week, one irrigation level was used to keep the soil moisture at the field capacity of the sandy soil at $90 \%$. The reduction in the moisture level was determined by using Moisture Tester Model KS-DI (Gypsum Block) during growing season. At the end of the experiment the total amount of irrigation water for each pot was calculated and presented in Tables (2), every plant received about 37.8 liters per pot of contaminated water. The field capacity of the sandy soil was determined by the pressure Cooker method at $1 / 3$ atm., as described by Israelsen and Hansen (1962). In both seasons, the plants were received by monthly spraying from $1^{\text {th }}$ February till $1^{\text {th }}$ April in both seasons. The plants also were sprayed with malic acid at concentrations of 0,250 and $500 \mathrm{ppm}$. Control plants were sprayed with tap water. On $30^{\text {th }}$ of April in the both two seasons, the plants were harvested.

In the two seasons, all plants received NPK chemical fertilization using soluble fertilizer (Agrico 20-20-20) at the rate of $1 \mathrm{~g} /$ pot. Fertilization was repeated every 15 days throughout the growing season (from the $3^{\text {th }}$ of January till the $15^{\text {th }}$ of April). In addition, weeds were removed manually upon emergence.

\section{Data recorded:}

\section{(1) Vegetative growth parameters}

Plant height $(\mathrm{cm})$, number of leaves per plant, leaves dry weight per plant $(\mathrm{g})$, leaves area $\left(\mathrm{cm}^{2}\right)$ according to Koller (1972), number branches per plant, branches dry weight $(\mathrm{g})$, root length $(\mathrm{cm})$ and root dry weight $(\mathrm{g})$.

\section{(2) Flowering growth parameters}

Number of florets per spike, spike length $(\mathrm{cm})$ and flower dry weight $(\mathrm{g})$.

(3) Chemical analysis determination:

- Total chlorophyll content was determined as a SPAD unites from the fresh leaves of plants for the different treatments under the experiment at the end of the season using Minolta (chlorophyll meter) SPAD 502 according to Yadava (1986).

- Total carbohydrates percentage in the leaves was determined according to Dubios et al.(1956).

- Determination of heavy metals content (Nickel). Plant samples were divided into leaves stem and roots. They were then dried at $72^{\circ} \mathrm{C}$ in an oven until completely dried. The dried plant samples were ground to powder. Element extraction was done according to Piper (1947) method and the concentration of heavy metal was determined using an atomic absorption spectrophotometer.

- Available heavy metal, i.e. (Nickel) in soil samples were extracted by DTPA solution according to Lindsay and Norvell (1978) and determined by Inductively Coupled Plasma Spectrometry.

Table 1: Chemical and physical analyses of the used sandy soil for the two successive seasons 2016 and 2017.

\begin{tabular}{|c|c|c|c|c|c|c|c|c|c|c|c|c|}
\hline \multirow[b]{2}{*}{ Season } & \multirow[b]{2}{*}{ pH } & \multirow{2}{*}{$\begin{array}{c}\mathrm{EC} \\
\left(\mathrm{dSm}^{-1}\right)\end{array}$} & \multicolumn{4}{|c|}{ Soluble cations (meq/l) } & \multicolumn{3}{|c|}{ Soluble anions (meq/l) } & \multicolumn{3}{|c|}{ Soil particles } \\
\hline & & & $\mathrm{Ca}^{++}$ & $\mathbf{M g}^{++}$ & $\mathrm{Na}^{+}$ & $\mathbf{K}^{+}$ & $\mathrm{HCO}_{3}^{-}$ & $\mathrm{Cl}^{-}$ & $\mathrm{SO}_{2}^{--}$ & $\begin{array}{c}\text { Sand } \\
(\%)\end{array}$ & $\begin{array}{l}\text { Silt } \\
(\%) \\
\end{array}$ & $\begin{array}{l}\text { Clay } \\
(\%) \\
\end{array}$ \\
\hline 2016 & 7.94 & 1.57 & 3.4 & 3.4 & 6.5 & 1.2 & 3.6 & 6.7 & 2.4 & 94.0 & 4.0 & 2.0 \\
\hline 2017 & 7.91 & 1.52 & 3.2 & 3.0 & 6.3 & 1.1 & 3.3 & 6.5 & 2.2 & 92.0 & 5.0 & 3.0 \\
\hline
\end{tabular}

Table 2: Total amount of the water used for each plant (l/pot) in each treatment during the growing two seasons 2016 and 2017.

\begin{tabular}{lccccc}
\hline \multirow{2}{*}{ Field Capacity (\%) } & \multicolumn{5}{c}{ Irrigation water (L) at months of first and second seasons } \\
\cline { 2 - 6 } & January & February & March & April & Total \\
\hline 90 & 4.80 & 9.75 & 11.25 & 12.00 & 37.8 \\
\hline
\end{tabular}


- Transfer factor (TF) is given by the relation: the ratio of the concentration of metal in the shoots to the concentration of metal in the soil (Chen et al., 2004). The transfer factor is a value used in evaluation studies on the impact of routine or accidental releases of pollutant into the environment.

The layout of the experimental design was split plot design with three replicates. Each replicate contained three plants. The main plots were the contaminated irrigation water levels, while the sup plots were the concentrations of malic acid. Data were subjected to analysis of variance (ANOVA) using the SAS program, SAS Institute (SAS Institute, 2002). The means of the individual factors and their interactions were compared by L.S.D test at $5 \%$ level of probability according to Snedecor and Cochran (1989)

\section{RESULTS}

\section{Vegetative growth parameters}

Data presented in Table (3) show that, in both seasons, irrigation with contaminated water with nickel decreased the vegetative growth of Salvia splendens plants, compared to plants irrigated with tap water (control). Plants irrigated with tap water had the highest mean values of plant height (46.53 and $50.42 \mathrm{~cm}$ ), number of leaves per plant (144.33 and 154.66), leaves dry weight (4.50 and $4.90 \mathrm{~g})$, leaves area $\left(1210.08\right.$ and $\left.1322.64 \mathrm{~cm}^{2}\right)$, number branches per plant (5.16 and 5.22), branches dry weight (5.16 and $5.73 \mathrm{~g}$ ), root length (46.48 and $50.92 \mathrm{~cm}$ ) and root dry weight (4.16 and $4.59 \mathrm{~g}$ ) in the first and second season, respectively. Moreover, raising the nickel concentration caused steady significant reductions in vegetative growth, with the highest concentration (300 ppm) giving significantly shortest plants with mean plant height (35.84 and $39.14 \mathrm{~cm})$, number of leaves per plant $(115.33$ and 122.33), leaves dry weight ( 3.45 and $3.77 \mathrm{~g}$ ), leaves area $\left(723.09\right.$ and $\left.787.40 \mathrm{~cm}^{2}\right)$, number branches per plant (3.77 and 4.16), branches dry weight (4.18 and $4.65 \mathrm{~g})$, root length $(34.47$ and $41.41 \mathrm{~cm})$ and root dry weight (3.30 and $3.65 \mathrm{~g}$ ) in the first and second season, respectively, than those received the other nickel concentration.

Vegetative growth was also significantly affected by spraying the plants with malic acid. In both seasons, vegetative growth was increased gradually when the malic acid concentration was raised from 0 ppm (control) to $500 \mathrm{ppm}$. Accordingly, it can be seen from the data in Table (3) that Salvia splendens plants sprayed with $500 \mathrm{ppm}$ malic acid were significantly highest with mean plant height (42.51 and $45.57 \mathrm{~cm}$ ), number of leaves per plant (133.75 and 143.75), leaves dry weight (4.11 and $4.41 \mathrm{~g}$ ), leaves area (1062.55 and $\left.1124.32 \mathrm{~cm}^{2}\right)$, number branches per plant (4.41 and 4.87), branches dry weight (4.72 and $5.20 \mathrm{~g}$ ), root length (41.99 and $47.08 \mathrm{~cm})$ and root dry weight $(3.70$ and $4.07 \mathrm{~g})$ in the first and second seasons, respectively, than plants sprayed with any other malic acid concentration.

Regarding the interaction between the effects of irrigation with contaminated nickel water and malic acid treatments on the vegetative growth of Salvia splendens plants, the highest values were obtained in the plants irrigation with tap water and sprayed with malic acid at $500 \mathrm{ppm}$ with mean plant height $(47.95$ and $51.70 \mathrm{~cm})$, number of leaves per plant (148 and 158), leaves dry weight (4.65 and $5.02 \mathrm{~g})$, leaves area $\left(1418.80\right.$ and $\left.1528.35 \mathrm{~cm}^{2}\right)$, number branches per plant (5.33 and 5.50), branches dry weight (5.11 and $5.68 \mathrm{~g})$, root length (48.16 and $52.04 \mathrm{~cm})$ and root dry weight $(4.31$ and $4.68 \mathrm{~g})$ in the first and second seasons, respectively). On the other hand, the shortest plants with mean plant height $(32.54$ and $36.37 \mathrm{~cm})$, number of leaves per plant (106 and 115), leaves dry weight (3.13 and $3.50 \mathrm{~g})$, leaves area (604.94 and $\left.674.37 \mathrm{~cm}^{2}\right)$, number branches per plant (3.16 and 4.00), branches dry weight (4.06 and $4.51 \mathrm{~g}$ ), root length (30.79 and $40.59 \mathrm{~cm})$ and root dry weight (3.13 and $3.49 \mathrm{~g})$ in the first and second seasons, respectively, were resulted in the plants irrigated with the highest nickel concentration $300 \mathrm{ppm}$ without malic acid treatment. It can also been seen from the data presented in Table (3) that in many cases, spraying the plants with malic acid reduced the undesirable effect of contaminated water with nickel.

\section{Flowering growth parameters}

The data presented in Table (4) show the effect of contaminated water with nickel on flowering growth formed on Salvia splendens plants. In both seasons, plants irrigation with tap water had the highest number of florets per spike (28.82 and 32.06), spike length (14.04 and $15.58 \mathrm{~cm})$ and flower dry weight $(10.92$ and $12.32 \mathrm{~g})$ in the first and second seasons, respectively. Accordingly, the lowest number of florets per spike (23.35 and 26.52), spike length (10.96 and $12.25 \mathrm{~cm})$ and flower dry weight (8.84 and $9.84 \mathrm{~g}$ ) in the first and second seasons, respectively, was formed by the plants that were irrigated with highest nickel concentration $300 \mathrm{ppm}$.

Concerning the effect of malic acid treatments on the flowering growth, the data recorded in Table (4) show that the treatment of malic acid $500 \mathrm{ppm}$ caused a significant increase in the number of florets per spike (26.39 and 29.09), spike length (12.85 and $14.12 \mathrm{~cm}$ ) and flower dry weight (9.99 and $10.98 \mathrm{~g}$ ) in the first and second seasons, respectively, compared to that of the control plants in the number of florets per spike (23.82 and 26.78), spike length $(11.60$ and $12.82 \mathrm{~cm})$ and flower dry weight $(9.02$ and $9.97 \mathrm{~g}$ ) in the two seasons, respectively. 


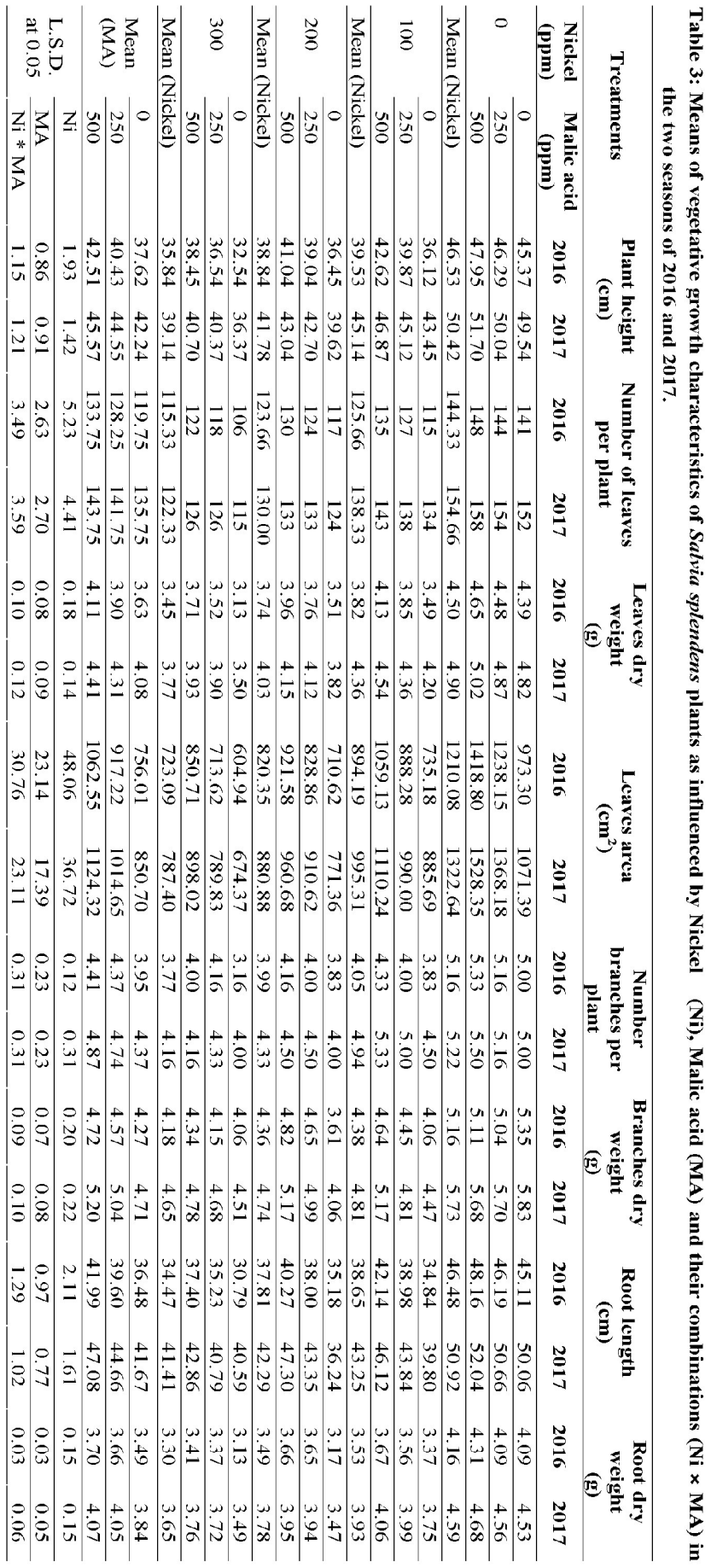


Table 4: Means of flowering growth characteristics of Salvia splendens plants as influenced by Nickel (Ni), Malic acid (MA) and their combinations ( $\mathrm{Ni} \times \mathrm{MA})$ in the two seasons of 2016 and 2017.

\begin{tabular}{|c|c|c|c|c|c|c|c|}
\hline \multicolumn{2}{|l|}{ Treatments } & \multicolumn{2}{|c|}{$\begin{array}{c}\text { Number of flowers } \\
\text { per spike }\end{array}$} & \multicolumn{2}{|c|}{$\begin{array}{c}\text { Spike length } \\
(\mathrm{cm})\end{array}$} & \multicolumn{2}{|c|}{$\begin{array}{c}\text { Flower dry weight } \\
\text { (g) }\end{array}$} \\
\hline $\begin{array}{l}\text { Nickel } \\
\text { (ppm) }\end{array}$ & $\begin{array}{c}\text { Malic acid } \\
\text { (ppm) }\end{array}$ & 2016 & 2017 & 2016 & 2017 & 2016 & 2017 \\
\hline \multirow{3}{*}{000} & 0 & 28.12 & 31.74 & 13.70 & 15.49 & 10.66 & 12.04 \\
\hline & 250 & 28.50 & 31.64 & 13.89 & 15.43 & 10.80 & 12.00 \\
\hline & 500 & 29.84 & 32.82 & 14.53 & 15.84 & 11.30 & 12.32 \\
\hline Mean (Nickel) & & 28.82 & 32.06 & 14.04 & 15.58 & 10.92 & 12.12 \\
\hline \multirow{3}{*}{100} & 0 & 22.67 & 25.66 & 11.05 & 12.14 & 8.59 & 9.44 \\
\hline & 250 & 24.82 & 27.34 & 12.10 & 13.07 & 9.41 & 10.16 \\
\hline & 500 & 25.93 & 28.67 & 12.63 & 14.05 & 9.82 & 10.93 \\
\hline Mean (Nickel) & & 24.47 & 27.22 & 11.92 & 13.08 & 9.27 & 10.17 \\
\hline \multirow{3}{*}{200} & 0 & 20.12 & 23.06 & 11.04 & 12.26 & 7.62 & 8.59 \\
\hline & 250 & 25.93 & 28.34 & 12.63 & 13.56 & 9.82 & 10.55 \\
\hline & 500 & 26.92 & 28.92 & 13.11 & 14.04 & 10.19 & 10.92 \\
\hline Mean (Nickel) & & 24.32 & 26.77 & 12.26 & 13.28 & 9.21 & 10.02 \\
\hline \multirow{3}{*}{300} & 0 & 22.67 & 25.60 & 9.81 & 11.04 & 8.58 & 9.53 \\
\hline & 250 & 23.17 & 26.83 & 11.28 & 12.72 & 8.77 & 9.90 \\
\hline & 500 & 24.21 & 27.14 & 11.79 & 12.99 & 9.17 & 10.10 \\
\hline Mean (Nickel) & & 23.35 & 26.52 & 10.96 & 12.25 & 8.84 & 9.84 \\
\hline \multirow{3}{*}{ Mean (MA) } & 0 & 23.82 & 26.78 & 11.60 & 12.82 & 9.02 & 9.97 \\
\hline & 250 & 25.51 & 28.56 & 12.42 & 13.71 & 9.66 & 10.66 \\
\hline & 500 & 26.39 & 29.09 & 12.85 & 14.12 & 9.99 & 10.98 \\
\hline \multirow{3}{*}{$\begin{array}{l}\text { L.S.D. at } \\
0.05\end{array}$} & $\mathrm{Ni}$ & 1.12 & 0.83 & 0.58 & 0.61 & 0.42 & 0.47 \\
\hline & MA & 0.43 & 0.33 & 0.18 & 0.21 & 0.16 & 0.17 \\
\hline & $\mathrm{Ni} * \mathrm{MA}$ & 0.57 & 0.44 & 0.24 & 0.28 & 0.21 & 0.22 \\
\hline
\end{tabular}

Data in Table (4) showed significant interaction in both seasons between the effects of irrigation with contaminated nickel water and malic acid treatments on flowering parameters formed by Salvia splendens plants. Combination between irrigation using tap water and spraying the plants with malic acid at $500 \mathrm{ppm}$ gave the highest number of florets per plant (29.84 and 32.82), spike length (14.53 and $15.84 \mathrm{~cm})$ and flower dry weight $(11.30$ and $12.32 \mathrm{~g}$ ) in the first and second seasons, respectively. On the other hand, the lowest number of florets per plant (22.67 and 25.60), spike length (9.81 and $11.04 \mathrm{~cm})$ and flower dry weight $(8.58$ and $9.53 \mathrm{~g}$ ) in the first and second seasons, respectively, were obtained in plants irrigated with the highest nickel concentration $300 \mathrm{ppm}$ and sprayed without malic acid.

\section{Chemical analysis determination}

\section{1. Total chlorophyll (SPAD) and Carbohydrate}

(\%) content

The results presented in Table (5) show that the highest content of total chlorophyll and carbohydrate content were obtained in the plant irrigated with tap water had the highest total chlorophyll content (27.70 and 27.81 SPAD) and carbohydrate content (13.03 and $13.02 \%)$ in the first and second seasons, respectively. Raising the nickel concentration in irrigation water resulted in steady significant reductions in the total chlorophyll content and carbohydrate content, which reached its lowest total chlorophyll content (25.13 and 25.35 SPAD) and carbohydrate content (11.66 and 11.87 $\%$ ) in the first and second seasons, respectively, in plants received the highest nickel concentration 300 ppm.

The results of leaf chemical analysis in Table (5) also show that the tested malic acid treatments had clear effect on the total chlorophyll content and carbohydrate content. The recorded mean values were ranged from total chlorophyll content (27.33 and 27.42 SPAD) and carbohydrate content (12.56 and $12.75 \%$ ) in the first and second seasons, respectively, in plants sprayed with $250 \mathrm{ppm}$ malic acid, total chlorophyll content (24.86 and 25.11 SPAD) and carbohydrate content (11.64 and 11.76 $\%$ ) in the first and second seasons, respectively, in plants sprayed with 0 ppm malic acid. 


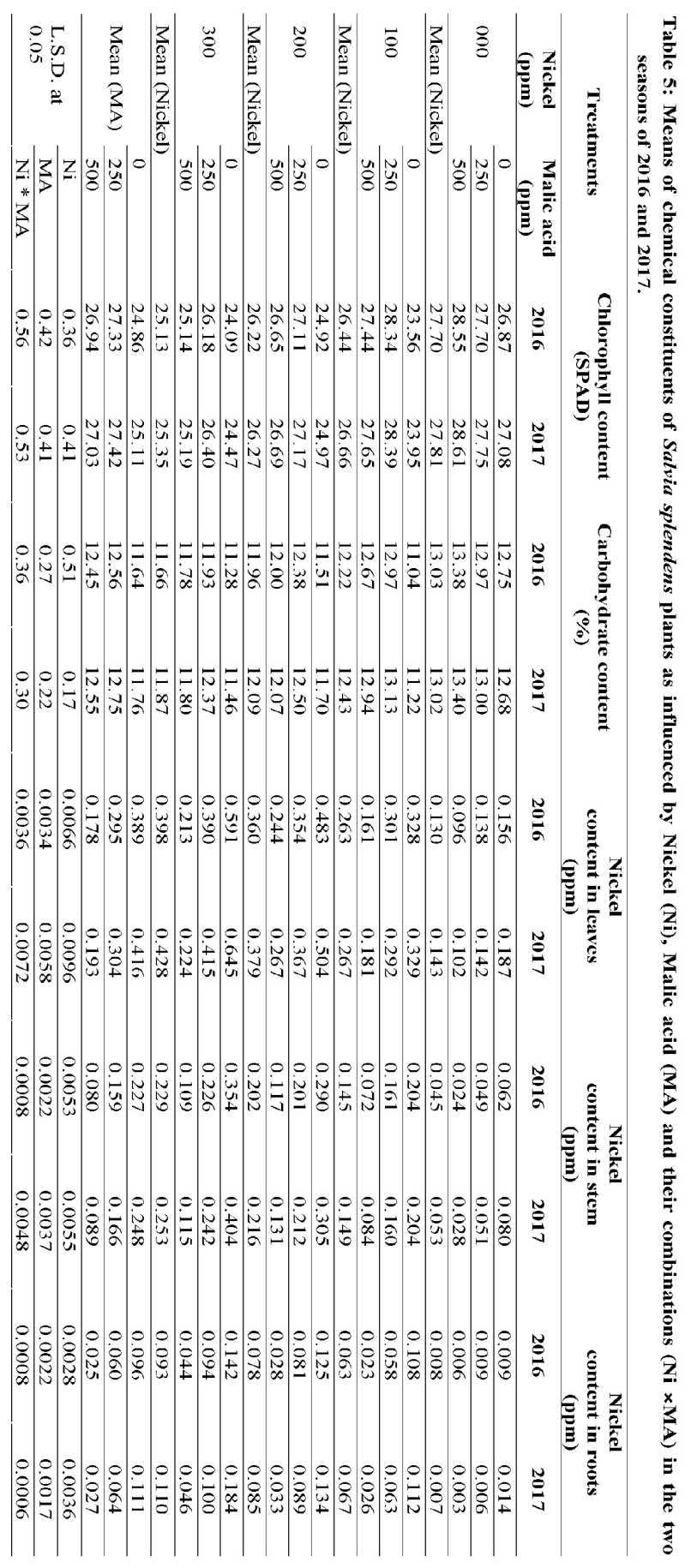


Regarding to the interaction between the effects of irrigation contaminated water with nickel and malic acid treatments, the data presented in Table (5) showed that the highest total chlorophyll contents of (28.55 and 28.61 SPAD) and carbohydrate content (13.38 and $13.40 \%)$ in the first and second seasons, respectively, were found in leaves of plants irrigated with tap water and sprayed with malic acid at $500 \mathrm{ppm}$,

\subsection{Nickel content in plant parts (ppm)}

The data resulting from plant parts chemical analysis in Table (5) showed that, the nickel content (ppm) in the plant part of Salvia splendens plants was raised steadily with raising the nickel concentration in the irrigation water. The lowest mean nickel content in leaves $(0.130$ and 0.143 ppm), nickel content in stem $(0.045$ and $0.053 \mathrm{ppm})$ and nickel content in root $(0.008$ and $0.007 \mathrm{ppm})$ in the first and second seasons, respectively, was found in the control plants, whereas the highest values content in leaves (0.398 and $0.428 \mathrm{ppm})$, nickel content in stem $(0.229$ and $0.253 \mathrm{ppm})$ and nickel content in root $(0.093$ and $0.110 \mathrm{ppm})$ in the first and second seasons, respectively, was found in plants irrigated with water containing the highest nickel concentration $300 \mathrm{ppm}$.

Concerning the effect of malic acid treatments on the nickel content in plant parts, the data recorded in the two seasons (Table 5) show that malic acid treatment 500 ppm caused a significant decrease in the nickel content in leaves giving mean values ( 0.178 and $0.193 \mathrm{ppm})$, nickel content in stem $(0.080$ and $0.089 \mathrm{ppm})$ and nickel content in root $(0.025$ and $0.027 \mathrm{ppm})$ in the first and second seasons, respectively, compared to that of control plants that had the highest nickel content in leaves (0.389and $0.416 \mathrm{ppm})$, nickel content in stem $(0.227$ and $0.248 \mathrm{ppm})$ and nickel content in root $(0.096$ and $0.111 \mathrm{ppm}$ ) in the first and second seasons, respectively.

Concerning the interaction between the effects of irrigation contaminated nickel water and malic acid treatments on the nickel content in plant parts (leaves stem and root). The results in (Table 5) show that the lowest nickel content in leaves $(0.096$ and $0.102 \mathrm{ppm})$, nickel content in stem (0.024 and 0.028 ppm) and nickel content in root (0.006 and 0.003 $\mathrm{ppm})$ in the first and second seasons, respectively, were obtained in the plant parts irrigated with tap water and sprayed with malic acid at $500 \mathrm{ppm}$. On the other hand, the highest nickel content was obtained in the plant parts that treated with nickel at $300 \mathrm{ppm}$ and receiving no malic acid treatment show that the highest nickel content in leaves $(0.591$ and $0.645 \mathrm{ppm})$, nickel content in stem $(0.354$ and $0.404 \mathrm{ppm})$ and nickel content in root $(0.142$ and $0.184 \mathrm{ppm})$ in the first and second seasons, respectively.

\section{Transfer factor (TF) of heavy metals}

Transfer factor (TF) indicates the efficiency of plants to transfer metals from its root to the aerial parts.

\subsection{Nickel content in soil samples (ppm)}

Data in Table (6) showed that the lowest average of nickel content was observed in soil cultured by untreated plants, while the highest average of nickel content was observed in soil after the treatment $300 \mathrm{ppm}$ nickel.

\subsection{Transfer factor to plant parts}

From the data presented in Table (7), it can be stated that the transfer factor in the parts of Salvia splendens plants was increased steadily with raising the nickel concentration in the irrigation water. Accordingly, the lowest transfer factor in leaves (0.941 and $0.967 \mathrm{ppm})$, transfer factor in stem $(0.328$ and $0.360 \mathrm{ppm})$ and transfer factor in root $(0.057$ and $0.052 \mathrm{ppm})$ in the first and second seasons, respectively, was found in plants irrigated with water containing $0 \mathrm{ppm}$ nickel (control), whereas the highest transfer factor in leaves $(2.412$ and $2.427 \mathrm{ppm})$, transfer factor in stem (1.395 and $1.443 \mathrm{ppm})$ and transfer factor in root (0.566 and $0.627 \mathrm{ppm})$ in the first and second seasons, respectively, was found in plants irrigated with water contained 300 ppm nickel.

The results in Table (7) also show that the transfer factor in the plant parts was reduced steadily with raising malic acid concentration. Accordingly, the highest transfer factor in leaves (2.631 and $2.608 \mathrm{ppm}$ ), transfer factor in stem (1.517 and $1.546 \mathrm{ppm})$ and transfer factor in root (0.637 and $0.687 \mathrm{ppm})$ in the first and second seasons, respectively, was recorded in the parts of control plants, whereas plants sprayed with the malic acid concentration $500 \mathrm{ppm}$ had the lowest transfer factor in leaves (1.047 and $1.062 \mathrm{ppm})$, transfer factor in stem $(0.467$ and $0.486 \mathrm{ppm})$ and transfer factor in root $(0.145$ and $0.144 \mathrm{ppm})$ in the first and second seasons, respectively.

Regarding the interaction between effect of irrigation contaminated water and malic acid concentrations on the transfer factor in the plant parts, the data in Table (7) show that the highest transfer factor in leaves (3.740 and $3.816 \mathrm{ppm})$, transfer factor in stem (2.240 and $2.390 \mathrm{ppm})$ and transfer factor in root $(0.898$ and $1.088 \mathrm{ppm})$ in the first and second seasons, respectively, was obtained in plants irrigated with nickel water at $300 \mathrm{ppm}$ and sprayed with tap water, while the lowest transfer factor in leaves (0.644 and $0.637 \mathrm{ppm})$, transfer factor in stem $(0.161$ and $0.175 \mathrm{ppm})$ and transfer factor in root $(0.040$ and $0.018 \mathrm{ppm})$ in the first and second seasons, respectively, was recorded in plants applied with $0 \mathrm{ppm}$ nickel and sprayed with 500 ppm malic acid. 
Table 6: Mean of nickel content in soil samples as affected influenced by nickel concentrations in water irrigation and foliar application of malic acid on Salvia splendens leaves at the end in the two seasons of 2016 and 2017.

\begin{tabular}{|c|c|c|c|}
\hline \multicolumn{2}{|c|}{ Treatments } & \multicolumn{2}{|c|}{$\begin{array}{c}\text { Nickel content in soil } \\
(\mathrm{ppm})\end{array}$} \\
\hline $\begin{array}{l}\mathrm{Ni} \\
(\mathrm{ppm})\end{array}$ & $\begin{array}{c}\text { Malic acid } \\
(\mathrm{ppm})\end{array}$ & 2016 & 2017 \\
\hline \multirow{3}{*}{$0 \mathrm{ppm}$} & $0 \mathrm{ppm}$ & 0.127 & 0.138 \\
\hline & $250 \mathrm{ppm}$ & 0.145 & 0.156 \\
\hline & $500 \mathrm{ppm}$ & 0.149 & 0.16 \\
\hline \multirow{3}{*}{100 ppm } & $0 \mathrm{ppm}$ & 0.142 & 0.153 \\
\hline & $250 \mathrm{ppm}$ & 0.153 & 0.164 \\
\hline & $500 \mathrm{ppm}$ & 0.166 & 0.177 \\
\hline \multirow{3}{*}{200 ppm } & $0 \mathrm{ppm}$ & 0.152 & 0.162 \\
\hline & $250 \mathrm{ppm}$ & 0.163 & 0.174 \\
\hline & $500 \mathrm{ppm}$ & 0.174 & 0.185 \\
\hline \multirow{3}{*}{300 ppm } & $0 \mathrm{ppm}$ & 0.158 & 0.169 \\
\hline & $250 \mathrm{ppm}$ & 0.168 & 0.179 \\
\hline & $500 \mathrm{ppm}$ & 0.181 & 0.195 \\
\hline
\end{tabular}

Table 7: Means of transfer factor to leaves, stem and roots of Salvia splendens plants as influenced by Nickel (Ni), Malic acid (MA) and their combinations $(\mathrm{Ni} \times \mathrm{MA})$ in the two seasons of 2016 and

\begin{tabular}{|c|c|c|c|c|c|c|c|}
\hline \multicolumn{2}{|l|}{ Treatments } & \multicolumn{2}{|c|}{$\begin{array}{c}\text { Transfer factor to } \\
\text { leaves } \\
\text { (TFL) }\end{array}$} & \multicolumn{2}{|c|}{$\begin{array}{c}\text { Transfer factor to } \\
\text { stem } \\
\text { (TFS) } \\
\end{array}$} & \multicolumn{2}{|c|}{$\begin{array}{c}\text { Transfer factor to } \\
\text { roots } \\
\text { (TFR) }\end{array}$} \\
\hline $\begin{array}{l}\text { Nickel } \\
\text { (ppm) }\end{array}$ & $\begin{array}{l}\text { Malic acid } \\
\text { (ppm) }\end{array}$ & 2016 & 2017 & 2016 & 2017 & 2016 & 2017 \\
\hline \multirow{3}{*}{000} & 0 & 1.228 & 1.355 & 0.488 & 0.579 & 0.070 & 0.101 \\
\hline & 250 & 0.951 & 0.910 & 0.337 & 0.326 & 0.062 & 0.038 \\
\hline & 500 & 0.644 & 0.637 & 0.161 & 0.175 & 0.040 & 0.018 \\
\hline Mean (Nickel) & & 0.941 & 0.967 & 0.328 & 0.360 & 0.057 & 0.052 \\
\hline \multirow{3}{*}{100} & 0 & 2.309 & 2.150 & 1.436 & 1.333 & 0.760 & 0.732 \\
\hline & 250 & 1.967 & 1.780 & 1.052 & 0.975 & 0.379 & 0.384 \\
\hline & 500 & 0.969 & 1.022 & 0.433 & 0.474 & 0.138 & 0.146 \\
\hline Mean (Nickel) & & 1.748 & 1.650 & 0.973 & 0.927 & 0.425 & 0.420 \\
\hline \multirow{3}{*}{200} & 0 & 3.177 & 3.111 & 1.907 & 1.882 & 0.822 & 0.827 \\
\hline & 250 & 2.171 & 2.109 & 1.233 & 1.218 & 0.496 & 0.511 \\
\hline & 500 & 1.402 & 1.443 & 0.672 & 0.708 & 0.160 & 0.178 \\
\hline Mean (Nickel) & & 2.250 & 2.221 & 1.270 & 1.269 & 0.492 & 0.505 \\
\hline \multirow{3}{*}{300} & 0 & 3.740 & 3.816 & 2.240 & 2.390 & 0.898 & 1.088 \\
\hline & 250 & 2.321 & 2.318 & 1.345 & 1.351 & 0.559 & 0.558 \\
\hline & 500 & 1.176 & 1.148 & 0.602 & 0.589 & 0.243 & 0.235 \\
\hline Mean (Nickel) & & 2.412 & 2.427 & 1.395 & 1.443 & 0.566 & 0.627 \\
\hline \multirow{3}{*}{ Mean (MA) } & 0 & 2.613 & 2.608 & 1.517 & 1.546 & 0.637 & 0.687 \\
\hline & 250 & 1.852 & 1.779 & 0.991 & 0.967 & 0.374 & 0.372 \\
\hline & 500 & 1.047 & 1.062 & 0.467 & 0.486 & 0.145 & 0.144 \\
\hline \multirow{3}{*}{ L.S.D. at 0.05} & $\mathrm{Ni}$ & 0.042 & 0.055 & 0.035 & 0.032 & 0.018 & 0.021 \\
\hline & MA & 0.021 & 0.033 & 0.013 & 0.022 & 0.014 & 0.010 \\
\hline & $\mathrm{Ni} * \mathrm{MA}$ & 0.028 & 0.044 & 0.016 & 0.028 & 0.016 & 0.011 \\
\hline
\end{tabular}

\section{DISCUSSION}

Plants grown in high nickel containing soil showed impairment of nutrient balance and resulted in disorder of cell membrane functions. Other symptoms observed in nickel treated plants were related with changes in water balance. High uptake of nickel induced a decline in water content of dicot and monocot plant species. The decrease in water uptake is used as an indicator of the progression of nickel toxicity in plants (Pandey and Sharma 2002; 
Gajewska et al., 2006). However, the information on the effect of excess concentrations of some metals (e.g. Nickel) on anti-oxidative processes is rare (Schickler and Caspi 1999), but they have been found to be useful to plants in lower concentrations while affecting them drastically at elevated concentrations. In addition, the symptoms of nickel toxicity appeared as a reduction in seedling growth. The growth of the main root is considerably affected and as a result, it exhibits the function of fibrous roots.

All vegetative growth parameters showed a significant reduction after treatment with different concentrations of nickel in water irrigation. These may be due to that nickel has some similar characteristics to $\mathrm{Ca}, \mathrm{Mg}, \mathrm{Mn}, \mathrm{Fe}, \mathrm{Cu}$, and $\mathrm{Zn}$. Therefore, nickel may compete with these metals in absorption and transpiration processes (Küpper et $a l$, 1996). Subsequently, this may affect important physiological processes, and ultimately result in toxic effects (Goncalves, 2007).

A significant decrease in total chlorophyll content was observed after irrigation with nickel contaminated water. Diminished chlorophyll concentration in the leaves of nickel treated plants might be due to replacement of central $\mathrm{Mg}$ from chlorophyll molecules by nickel (Küpper et al., 1996). Further, decline in chlorophyll concentration (Gajewska et al., 2006) in leaves of nickel treated plants may also be attributed to increase interruption in pigment synthesis and/or increase in degradation of chlorophyll (Sheoran et al., 1990) and (Molas, 1997) ultimately leading to low photosynthetic rates and lower biomass accumulation.

The results showed that there was a significant decrease in total carbohydrate percentage after irrigation with nickel contaminated water. This decrease may be due to reductions in leaf blade area and leaf density (Molas, 1997). Overall, reductions in plant yield can be attributed to poor plant development (Ahmad et al., 2007). These results are in harmony with those were obtained by (Srivastava et al., 2012) on Pisum sativum L. seedlings.

The increase in nickel content in dried leaves and roots is probably because plant shaves efficient root absorption mechanisms which allow them to specifically accumulate metals from soils and/or water. After root absorption, nickel can be transported quickly into shoots and leaves and then sequestrated in the vacuole (Milner and Kochian, 2008). These results are in agreement with those reported by (Skoula et al., 2003) on chamomile, sage (Salvia officinalis) and thymus (Thymus vulgaris).

\section{CONCLUSIONS}

Phytoremediation is a new cleanup concept that involves the use of plants to clean or stabilize contaminated environments. Phytoremediation of heavy metals is the most effective plant-based method to remove pollutants from contaminated lands as a result of irrigation with water contaminated with heavy metals. This green technology can be applied to remediate the polluted soils without creating any destructive effect of soil structure. Phytoremediation of contaminated water and soil using non-edible plant like Salvia splendens offers an environmental friendly and cost-effective method for remediating the polluted soil with heavy metals. The Salvia splendens have noticeable potential to absorb toxic heavy metals. This method has been able to use wastewater contaminated with heavy metals in the irrigation of ornamental plants while maintaining soil fertility.

\section{REFERENCES}

Ahmad M.S.A., M. Hussain, R. Saddiq and A. K. Alvi (2007). Mungbean: A nickel indicator, accumulator or excluder?, Bull. Environ. Contam.Toxicol., 78: 319-324.

Chen Y., Shen Z. and Li X. (2004). The use of vetiver grass (Vetiveria zizanioides) in the phytoremediation of soils contaminated with heavy metals. Applied Geochemistry 19, 1553-1565.

da Silva J. A. (2003). The cut flower: postharvest considerations. Journal of Biological Sciences, vol. 3, no. 4, pp. 406-442.

Day D.A. and Hanson J.B. (1977). Pyruvate and malate transport and oxidation in corn mitochondria. Plant Physiology, 59(4):630635.

Duarte B., Delgado M. and Cador I. (2007). The role of citric acid in cadmium and nickel uptake and translocation in Halimione portulacoides. Chemosphere, 69: 836-840.

Dubios M., Gilles K., Hamlton J., Rebers P. and Smith F. (1956). Colourimetric method for determination of sugars and related substances. Analytical Chemistry, 28(3): 350356.

Gajewska E., Sklodowska M., Slaba M. and Mazur J. (2006). Effect of nickel on antioxidative enzymes activities, proline and chlorophyll contents in wheat shoots. Biol Planta, 50(4): 653-659.

Goncalves S.C. (2007). Genetic diversity and differential in vitro responses to $\mathrm{Ni}$ in Cenococcum geophilum isolates from serpentine soils in Portugal. Mycorrhiza, 17: 677-686. 
Govindasamy C., Arulpriya M., Ruban P., Francisca L.J. and Ilayaraja A. (2011). Concentration of heavy metals in seagrasses tissue of the Palk Strait, Bay of Bengal. International Journal of Environmental Sci., 2(1): 145-153.

Israelsen, O. and V. Hansen. 1962. Irrigation, Principles and Practices. John Wiley and Sons, Inc. New York.

Jackson N. L. (1958). Soil Chemical Analysis.Constable. Ltd. Co., London, 498 p.

Karousou, R., E. Hanlidou, and S. Kokkini. 2000. The sage plants in Greece: Distribution and infraspecific variation, p. 27-46. In: S.E. Kintzios (ed.). Sage: The genus Salvia. Harwood Academic Publishers, Amsterdam, The Netherlands.

Koller H.R. (1972). Leaf area, leaf weight relationship in the soybean canopy. Crop Sci., 12: $180-183$.

Kupper H. and Kroneck P.M.H. (2007). Metal Ions in Life Sciences (Eds: A. Sigel, H.Sigel, R.K.O.Sigel), Vol. 2, John Wiley\& Sons, Chichester, UK. : 31-62.

Küpper H., F. Küpper and M. Spiller (1996). Environmental relevance of heavy metal substituted chlorophyll using the example of water plants. J. Exp. Bot., 47: 259- 266.

Lindsay W.L. and Norvell W.A. (1978). Development of a DTPA soil test for zinc, iron, manganese and copper. Soil Sci. Soc. Am. J., 42: 421-428.

MadhavaRao K.V. and Sresty T.V. (2000). Antioxidative parameters in the seed- lings of pigeon pea (Cajanus cajan (L.) Millspaugh) in response to $\mathrm{Zn}$ and Ni stresses. Plant Sci., 157: 113-128.

Milner M.J. and L. V. Kochian (2008). Investigating heavy-metal hyper-accumulation using Thlaspicaerulescens as a model system. Ann. Bot., 102: 3-13.

Molas J. (1997).Changes in morphological and anatomical structure of cabbage (Brassica oleracera L.) outer leaves and in ultrastructure of their chloroplasts caused by an in vitro excess of nickel.Photosynth., 34: $513-522$.

Molas J. (2002). Changes of chloroplast ultrastructure and total chlorophyll concentration in cabbage leaves caused by excess of organic Ni (II) complexes. Environ. Exp. Bot., 47: 115-126.

Mulrooney S.B. and Hausinger R.P. (2003). Nickel uptake and utilization by microorganisms. FRMS Microbiol, Rev., 27: 239-261.
Pandey N. and Sharma C.P. (2002). Effect of heavy metals $\mathrm{Co}_{2}, \mathrm{Ni}_{2}$, and $\mathrm{Cd}_{2}$ on growth and metabolism of cabbage. Plant Sci 163: 753758.

Piper O.S. (1947). Soil and plant Analysis. Adelaite Univ., Adelaide, Australia : 258-275.

Rafii M.Y., Shabanimofrad M., Wahab P.E.M. and Latif M.A. (2012). Analysis of the genetic diversity of physic nut, Jatropha curcas L. accessions using RAPD markers. Mol. Biol. Rep., DOI 10.1007/s11033-012-1478-2.

Ragsdale S.W. (1998). Nickel biochemistry. Curr. Opin. Chem. Biol., 2: 208-215.

Rainbow P.S.: Trace metal bioaccumulation (2007). Models, metabolic availability and toxicity. Environ. Int., 33, 576-582.

Salt D.E. (2000). Phytoremediation of contaminated soil and water. Eds. N. Terry. G. Banuelos. Lewis Publishers. Boca Raton. FL., 189-200.

SAS Institute (2002). SAS user guide and program 20 version 9.0.38. cary, NC27513.

Schickler H. and Caspi H. (1999). Response of antioxidative enzymes to nickel and cadmium stress in hyperaccumulator plants of the genus Alyssum. Physiol Plant 105: 39-44.

Sharma B.D., Mukhopadhyay S.S. and Katyal J.C. (2006). Distribution of total and DTPAextractable zinc, copper, manganese and iron in vertisols of India. Commun Soil Sci Plant Anal., 37, 653-672.

Sheoran I.S., H.R. Singal and R. Singh (1990).Effect of cadmium and nickel on photosynthesis and enzymes of the photosynthetic carbon reduction cycle in pigeon pea (Cajanus cajan L.).Photosynth. Res., 23: 345-351.

Skoula M., M. Fabian and N. Lydakis-Simantiris (2003). Cadmium, nickel, and lead accumulation in chamomile, thyme and sage, grown on heavy metal-enriched soil. In: Proceedings of the $2^{\text {nd }}$ European Bioremediation Conference: 329-332.

Snedecor, G. W and W. G. Cochran (1989). Statistical Methods, $6^{\text {th }}$ ed, Iowa State Uni, Press, Ames, Iowa, PP: 245-250.

Srivastava G., S. Kumar, G. Dubey, V. Mishra and S.M. Prasad (2012). Nickel and ultraviolet-B stresses induce differential growth and photosynthetic responses in Pisum sativum L. seedlings .Biol. Trace., 149 (1): 86-96.

Topcu, G. 2006. Bioactive triterpenoids from Salvia species. J. Nat. Prod. 69: 482-487.

Wu, L., X. Guo, and A. Harivandi. 2001. Salt tolerance and salt accumulation of landscape plants irrigated by sprinkler and drip irrigation systems. J. Plant Nutr. 24: 14731490 . 
Wua G., Kanga H., Zhangc X., Shaob H., Chuc L. and Ruand C. (2010). A critical review on the bio-removal of hazardous heavy metals from contaminated soils: Issues, progress, ecoenvironmental concerns and opportunities. J.

Haz. Mat., 174, 1-8.
Yadava U. (1986). A rapid and nondestructive method to determine chlorophyll in intact leaves. Hort. Sci., 21(6): 1449-1450.

\section{تأثير النيكل فى ماء الرى والرش بحض الماليك على النمو الخضرى والإزهار والتركيب الكيماوى لنباتات السلقيا المستديمة}

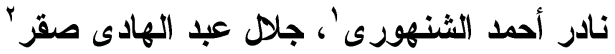

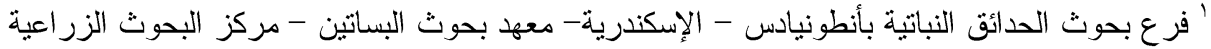

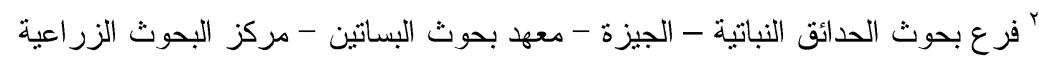

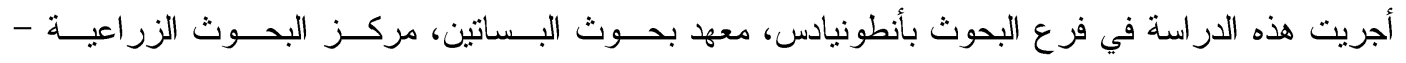

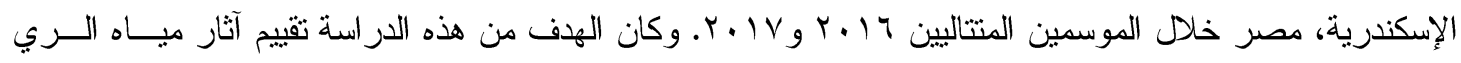

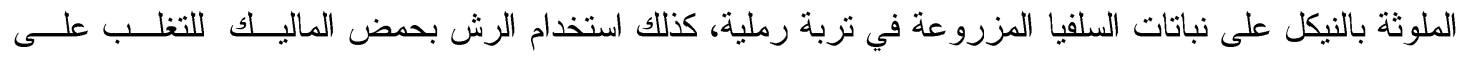

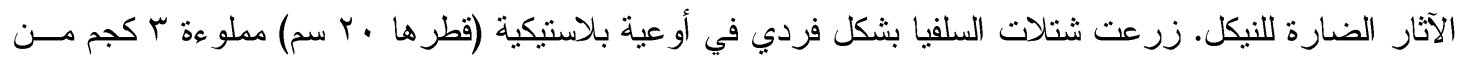

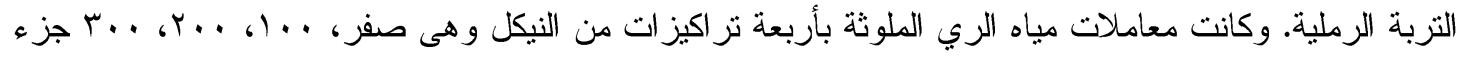

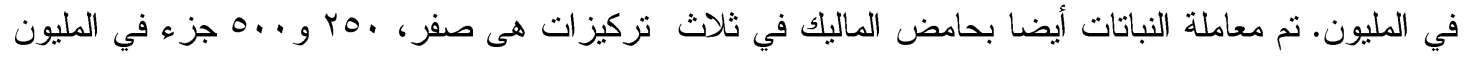
عن طريق الرش شهريا في كلا الموسمين.

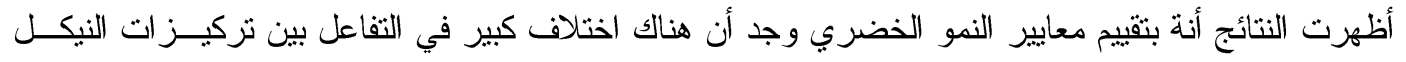

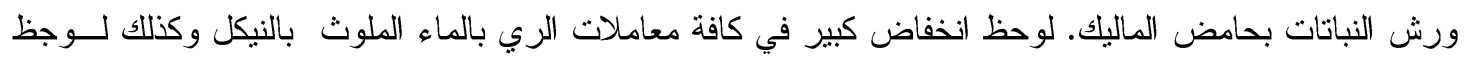

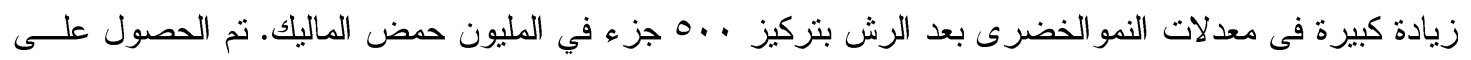

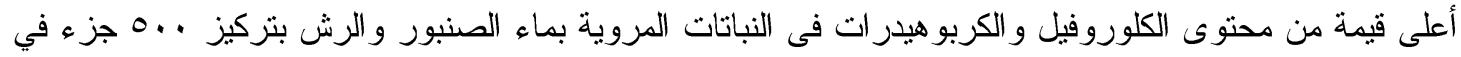

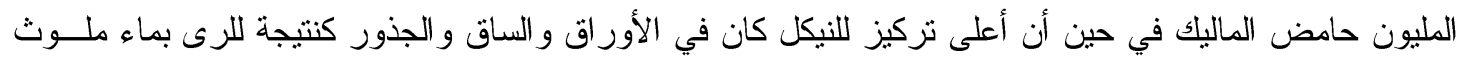

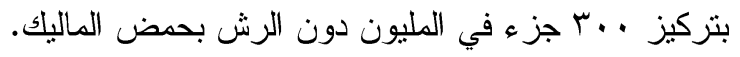

